\title{
$\mathrm{X}$ 線 CT を用いたウレタンフォーム製マットレスの変形形状計測手法の検討
}

船井 孝 ${ }^{* 1},{ }^{* 2,}{ }^{* 3}$ ，横田 秀夫 ${ }^{* 2,}{ }^{* 4}$ ，袴田 恭正 ${ }^{* 5}$ ，深作 和明 ${ }^{* 6}$ 姫野 龍太郎 ${ }^{* 7, * 8}$ ，鈴木 敬明 ${ }^{* 9}$ ，前嶋 文明 ${ }^{* 5}$ ，中村 佐紀子 ${ }^{* 6}$

\section{Novel measuring method of urethane-foam mattress deformation using X-ray CT}

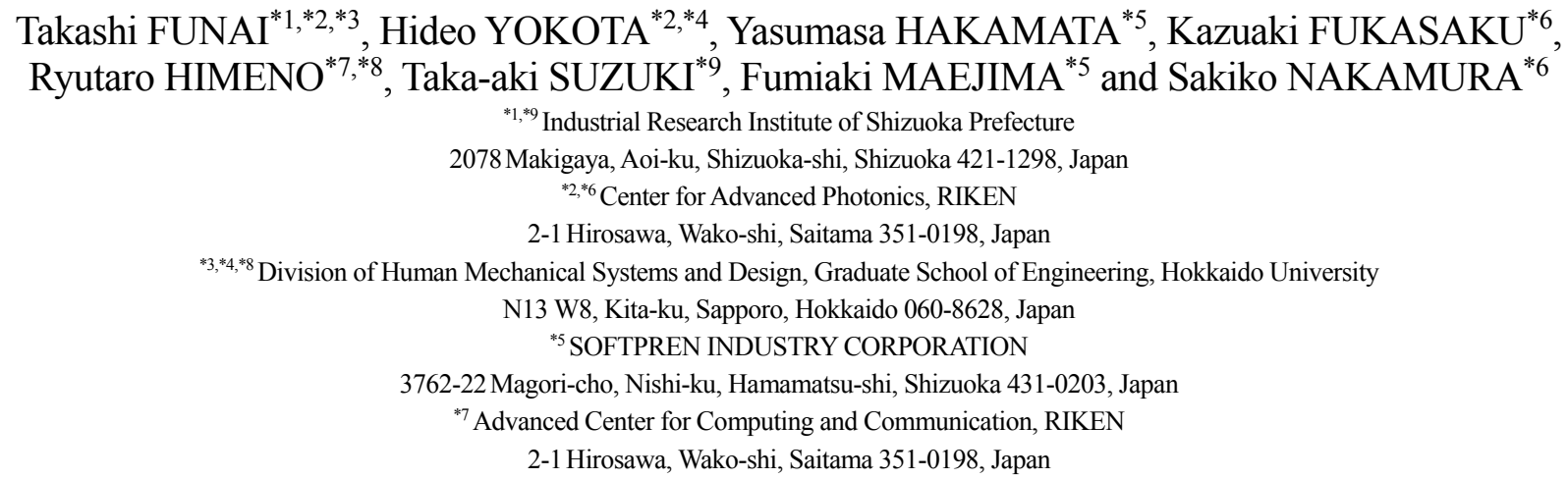

Received: 1 October 2017; Revised: 5 January 2018; Accepted: 15 February 2018

\begin{abstract}
A novel method to measure the deformation of a urethane-foam object using an X-ray computed tomography (X-ray CT) technique was proposed and examined. The proposed method is made up of following two steps. First, X-ray sensitive 'contrast media' were drawn in lattice-like manner on top and bottom surfaces and internal planes of urethane-foam, which enabled visualization of the drawn positions in CT images. Second, position data of contrast media were then converted into the numerical values in a prescribed coordinate to measure the deformation. It was found that the contrast media successfully visualized outer and internal displacement with the urethane-foam deformation, and the comprehensive error of measurement was $0.3 \mathrm{~mm}$ in root mean square. As a trial for further practical purpose, the deformation of the urethane-foam mattress with a human-body model on it was measured using this method. A urethane-foam mattress with contrast media was prepared, a human trunk model was set on the mattress, and the mattress with the model was subjected to X-ray CT. The deformation state at surface of, and especially inside of, the mattress could be visualized and measured. We concluded that the proposed method could bring us an information on deformation state of the urethane-foam and the urethane-foam mattress as numerical values.
\end{abstract}

Keywords : Mattress, Measurement, Accuracy, X-ray CT, Biomedical engineering

\section{1. 緒言}

マットレスの変形量や寝姿勢は，寝心地や身体負荷と密接な関係があることが報告されている．田村らは肩甲 骨部で $3 \mathrm{~cm}$ ，仙骨部で $4 \mathrm{~cm}$ 沈み込む布団が好まれることを示し，山崎らはクッション特性の違いによる寝姿勢

No.17-00443 [DOI:10.1299/transjsme.17-00443], J-STAGE Advance Publication date : 22 February, 2018

${ }^{*} 1$ 正員，静岡県工業技術研究所（广421-1298 静岡県静岡市葵区牧ヶ谷 2078）

*2 正員, (国研) 理化学研究所（广351-0198 埼玉県和光市広沢 2-1）

*3 正員, 北海道大学大学院工学院（ $\bar{T} 060-8628$ 北海道札幌市北区北 13 条西 8 丁目 $)$

$*_{4}^{*}$ 正員, 北海道大学大学院工学研究院

*5 ソフトプレン工業（株）（テ431-0203 静岡県浜松市西区馬郡町 3762-22）

*6 (国研) 理化学研究所

*7 正員, フェロー, (国研) 理化学研究所

*8 正員, フェロー, 北海道大学大学院工学研究院

*9 静岡県工業技術研究所

E-mail of corresponding author: takashi1_funai@iri.pref.shizuoka.jp 
Funai, Yokota, Hakamata, Fukasaku, Himeno, Suzuki, Maejima and Nakamura, Transactions of the JSME (in Japanese), Vol.84, No.859 (2018)

の変化が身体負荷に大きく影響することを示した（田村他, 1989，山崎他, 1994）。また，寝姿勢と睡眠にも密接な 関係があることが報告されており，小暮らは入眠姿勢で葠心地が良いと感じるマットレスは，中途覚醒から再入 眠までの時間が短縮されることを示した（小暮他, 2007)。このように，良好な寝心地や身体負荷の少ないマット レスを開発するためには，使用時のマットレス変形量や寝姿勢を把握する必要がある．また，身体負荷を評価す るためには，人体内部の状態も把握する必要がある.

人体の形状を再現した三次元モデルを使った力学的シミュレーション (以下, 生体力学シミュレーション) は, 製品および人体の内部状態の予測が期待できる技術である，そのため，マットレスをはじめとした医療や福祉機 器の開発に有効なツールであり，マットレス変形量や寝姿勢の実験を伴わない予測が期待できる. これまでに生 体力学シミュレーション技術の開発に関する様々な研究が行われてきた（横田他, 2005, Ijiri and Yokota, 2010, 船井 他, 2008, 横田, 姫野,2008, 長岡他, 2002) . 著者らはこれらの技術を活用し, 使用者の体型に合わせたマットレス 開発を検討している. マットレス開発に活用できる生体力学シミュレーション技術を確立するためには, 実験結 果との比較を行うことでシミュレーション結果の信頼性を担保する必要がある. 例えば，仰臥位におけるマット レスの変形を再現するシミュレーションでは, マットレスの変形状態や人体内部の状態を数值化し，シミュレー ションの結果と比較する必要がある。近年のマットレスは, 体圧分散性能を高めるために厚さ方向に異なる材料 を積層した構造で設計される.このようなマットレスの内部では, 変形やひずみが不均一となる. このことから, シミュレーション結果との比較には, マットレス内部の変形やひずみの分布を実験的に計測する必要がある.

マットレス変形形状計測については，これまでに様々な手法が試みられている．嶋根らはマットレス使用時の 体圧分布を推定するために石膏包帯法によるマットレス変形量測定手法を提案した (嶋根, 田村, 1993)。また河 合らは，より簡易的に計測する方法として縦向きスライディングゲージ法を提案し，中嶋はひずみゲージを使っ た寝姿勢計測装置を開発した（河合他, 1998, 中嶋, 1998)。これらの計測はマットレス変形形状あるいは寝姿勢の 計測手法としては有効であるが，いずれの手法も計測誤差についての検討がなされていない. またこれらの手法 では，人体およびマットレス表面の変形量のみ計測可能であり，人体やマットレス内部の状態は考慮されていな い. 山田らが実施した二層式マットレスの変形計測は, 直方体試験片を円筒型圧子で圧縮した側面からの観察結 果に基づいたものであり, 試験片側面の奥行き方向に一様となる変形に限り内部の変形状態を可視化した（山田 他, 2016). しかしながら，使用者が臥床した際に生じるウレタンフォーム内部の三次元的なひずみ分布の把握は 想定されていない. 人体内部の状態観察には, X 線 CT (X-ray Computed Tomography) や MRI (Magnetic Resonance Imaging）のような医療用機器が必要となる. 被験者がマットレスに臥床した際の人体内部の状態については, 佐 藤が MRI を活用したマットレス上での仰臥位腰椎アライメントの計測方法を示しているが，この報告について もどの程度の計測誤差を有しているかの検討がなされていない（佐藤, 1995)。 また, 腰椎の相互位置関係のみを 対象としており，マットレスの変形形状は考慮していない. Yonezu らはX線 CT によるウレタンフォームの内部 観察を行ったが, 多孔質構造の観察を目的としたため, 変形量計測への応用は行っていない (Yonezu et al., 2016).

本研究では, 場所によって異なる硬さのウレタンフォームを配置, あるいは積層した構造のマットレスと人体 内部の状態観察を見据えた，X 線 CT を用いたウレタンフォームの変形形状計測手法について検討した. 医療で 使われる X 線 CT は, 対象の様々な断面をひずみが少なく, 高い分解能で撮影可能である. 反面, X 線 CT は撮 影対象の密度, 寸なわち X 線透過度の差を画像化するため, ウレタンフォームのように密度がほぼ一様な素材の 場合, 変形形状の可視化は極めて困難である. 前橋らは, X 線 CT によるウレタンフォーム内部観察で任意断面 のウレタンフォーム表面の変形状態の撮影を行ったが，断層画像のウレタンフォーム内部はほぼ一様に撮影され た（前橋他, 2017). しかしながら, X 線 CT で内部の変形を可視化できれば, 得られる断層画像の画像処理によ り, ウレタンフォームの変形形状計測が可能となる. また, そのウレタンフォームでマットレスを作製すれば, 使用者がそのマットレスに臥床した状態を撮影寸ることで, 佐藤の報告と同様の人体内部観察とマットレスの変 形形状計測が同時に可能となり, 生体力学シミュレーションと比較できる有用な情報を得ることが期待できる. そこで本研究では, 造影剤を塗布した変形状態にあるウレタンフォームをX線 CT で撮影し, 得られた断層画像 から変形量を計測する手法を提案した。 この提案手法では, 画像処理による計測誤差が見込まれる. ウレタンフ オームの硬さは, JIS K6400-2 に示される直方体試験片を円板型圧子で圧縮した結果で代表され, 金井らは自動車 用シートの評価に向けた素材選定をこの試験結果に基づいて行った（JIS K6400-2, 2012, 金井他, 2004). 本研究で は, この規格に示される試験方法を参考にした圧縮試験を基準として, 提案手法の計測誤差を評価した. 続いて 
Funai, Yokota, Hakamata, Fukasaku, Himeno, Suzuki, Maejima and Nakamura,

Transactions of the JSME (in Japanese), Vol.84, No.859 (2018)

提案手法をマットレスに適用し，人がマットレスに臥床した際の体幹部付近のマットレス変形形状が計測できる マットレス（撮影用マットレス）の作製を試みた．撮影用マットレスに人体の体幹部形状とその重量を再現した 人体模型を載せ，マットレス変形形状計測を行った．これらの評価・検討により，計測誤差を明確に示したウレ タンフォーム製マットレスにおける表面および内部の変形形状計測を検討した.

\section{X X 線 CT によるウレタンフォームの変形形状計測と計測誤差評価}

\section{$2 \cdot 1$ 造影剤を含んだウレタンフォーム試験片の作製}

$\mathrm{X}$ 線 CT 撮影で得た断層画像からウレタンフォームの変形形状を計測するためには, ウレタンフォームに塗布 した造影剤が，断層画像に点として撮影されると都合がよい，そこで本研究では，ウレタンフォームの表面およ び内部に格子状に造影剤を塗布することとした．JIS K6400-2 では， $380 \mathrm{~mm} \times 380 \mathrm{~mm} \times 50 \mathrm{~mm}$ の試験片を $\varphi 200$ $\mathrm{mm}$ の圧子で圧縮するが，本研究では X 線 CT で撮影可能な大きさおよび想定するマットレスの厚さから, 試験 片形状を $300 \mathrm{~mm} \times 300 \mathrm{~mm} \times 100 \mathrm{~mm}$ ，圧子の大きさを $\phi 100 \mathrm{~mm}$ とした．まず，図 1(a)に示すように，300×300 $\times 100 \mathrm{~mm}$ のウレタンフォームを 4 枚のシートに切断し，各シートの上面および上から 4 枚目のシート下面に造 影剤を格子状に塗布した（図 1(b) 1st layer～5th layer)。造影剤の乾燥後に各シートを接着し，表面ならびに内部に 格子状の造影剤を有する $300 \times 300 \times 100 \mathrm{~mm}$ のウレタンフォームの試験片を作製した（図 1(c)，(d)，(e)）．試験片 は，マットレスに使用される（株）イノアックコーポレーション製のウレタンフォーム ER-1 で作製した. 造影剂

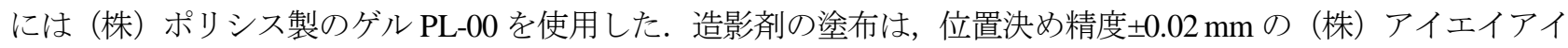
製 IS 型単軸電動アクチュエーターを組み合わせた直行型 3 軸ロボットで行った。電動モータで駆動するトロコ イドポンプにより圧送された造影剤を，250 mm/sec.で駆動するロボットのアームに取り付けた内径 $\varphi 6 \mathrm{~mm} の ノ$ ズルから送り出し，各シートに塗布した．シートの接着には，ノガワケミカル（株）製ダイアボンドDS119を使 用した．接着後に造影剤の幅を確認したところ約 $5 \mathrm{~mm}$ であった.
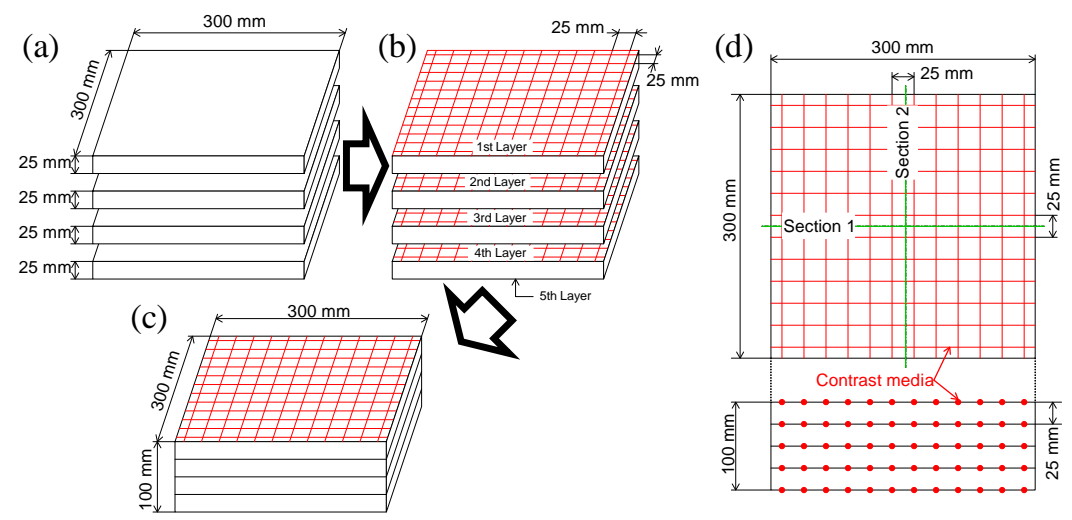

(e)

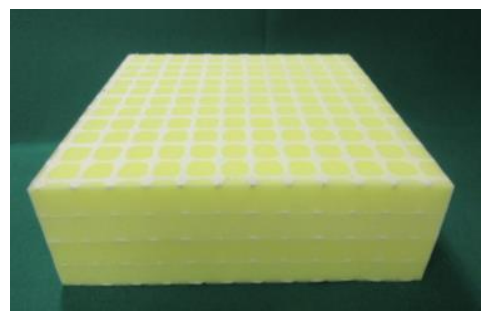

Fig. 1 Preparation of a specimen submitted to an experiment. (a) Four urethane-foam sheets were used. (b) Lattice-like lines were drawn using contrast media on top surface of each sheet and bottom surface of the lowest sheet. (c) They were piled up and glued. (d) Sections to be used in measurement of deformation were at the cross-sections named section 1 and 2. (e) A photograph of the specimen.

\section{$2 \cdot 2 \quad \mathrm{X}$ 線 CT 撮影およびウレタンフォームの変形形状計測}

作製した試験片を図 2(a)に示す治具とウェイトを用いて圧縮し，X 線 CT で撮影した．治具は X 線 CT 撮影に おけるアーチファクトの発生を回避するため, ベニヤ板とポリ塩化ビニル製パイプで作製した. 圧縮する荷重は, 5.2，10，20，30，40，50，60 N とした．ウェイトは，圧子を含めた重量が各圧縮荷重と等価となるように，樹脂 製ケースに食塩（NaCl 99\%）を充填して作製した．X 線 CT 撮影は PHILIPS 社製 Brilliance CT16 で圧縮荷重ごと

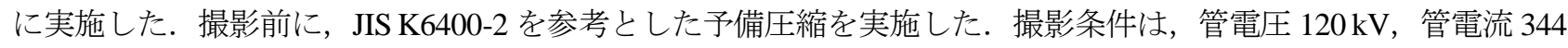
$\mathrm{mA}$ であった。この撮影条件は人体の脊椎を撮影する際の条件と同じである．スライス厚は $1 \mathrm{~mm}$ とした．撮影 後, 約 $1 \mathrm{~mm}$ ピッチのボクセルデータとなるように再構成を行った. 再構成後, 図 1(d)に示す Section 1, 2 断面の 
Funai, Yokota, Hakamata, Fukasaku, Himeno, Suzuki, Maejima and Nakamura,

Transactions of the JSME (in Japanese), Vol.84, No.859 (2018)

画像を抽出した．抽出した画像の例として，40N で圧縮したときの断層画像を図 2(b)に示す. 画像に目立ったア 一チファクトは確認されなかった. 圧縮に使用した治具や圧子に加えて, ウレタンフォームに塗布した造影剂が, 点となって撮影できていることを確認した.

続いて，図 2(b)の撮影結果に対してウレタンフォームの変形形状計測を試みた．点として撮影された造影剤の 位置を座標值として得ることができれば, ウレタンフォームの変形形状を数值として扱うことができる.そこで, ウレタンフォームの変形形状計測として, 図 2(b)のように画像の左下を原点とする X-Y 座標系を作成し, 画像処 理による造影剤の位置の数值化を試みた。まず，図 2(b)で確認される造影剂の像とその他の領域を分ける二值化 作業を, 画像処理ソフトウェア ImageJ（Rasband, 1997-2016, Schneider et al., 2012, Abràmoff et al., 2004）のプラグイ ン機能”Trainable Weka Segmentation”（Arganda-Carreras et al., 2017）で実施した。造影剂各点の座標值計測では, ImageJ の機能”Analyze Particles”で，輝度值による重みづけを行い，各像の重心座標を計測した．計測は，DICOM の Tag 情報に記載された 1 画素当たりの長さを反映した結果が出力されるように配慮した. 今回の撮影では, 図 2(b)に示す X, Y 方向の 1 画素当たりの長さがそれぞれ $1 \mathrm{~mm}$ であった. 続いて圧縮治具の基準板上面（図 2(b)の 点 $\mathrm{A}, \mathrm{B})$ の $\mathrm{Y}$ 方向座標を読み取った。 得られた $\mathrm{Y}$ 座標値の平均值を計算し, 計測された造影剤の $\mathrm{Y}$ 座標值から 減じて基準板上面を $\mathrm{Y}^{\prime}=0$ とした $\mathrm{X}^{\prime}-\mathrm{Y}^{\prime}$ 座標系の值とした. 得られた各造影剤の座標值に基づき, 横軸 $\mathrm{X}^{\prime}[\mathrm{mm}]$, 縦軸 $\mathrm{Y}^{\prime}[\mathrm{mm}]$ としたグラフを作成し, 変形形状を可視化した. ウレタンフォームの変形形状を数值化した例とし て, 圧縮荷重 $40 \mathrm{~N}$ の結果を図 3 に示す．ウレタンフォーム表面に相当する 1 st layer のプロットより, ウレタン フォーム表面の変形後の形状が表現できていることが確認され，提案手法によりウレタンフォーム表面の変形状 態を数值として扱うことができた．また，ウレタンフォーム内部に塗布した造影剤により，2nd layer〜4th layerの プロットが作成され，ウレタンフォーム表面だけでなく内部の変形状態を数值化することができた.

続いて, ウレタンフォームの圧縮荷重と変形量の関係を求めた. 圧縮荷重ごとに得た Section 1，2 の断層画像 の圧子の直下には，それぞれ 4 個，合計 8 個の造影剤が撮影されていた（図 2(b)）。 また図 2(b)の示した基準板

(Base Plate) 上面の点 A，B の Y 座標も, Section 1，2の断層画像からそれぞれ 2 点，合計 4 点計測できる. 圧 縮荷重ごとに造影剂の $\mathrm{Y}$ 座標值の平均值および点 $\mathrm{A}, \mathrm{B}$ の $\mathrm{Y}$ 座標值の平均值を計算し, その差, すなわち基準板 上面から圧子直下の造影剤までの Y 軸方向距離を算出した. その後, 圧縮荷重ごとに得たこの距離を圧縮荷重 5.2 $\mathrm{N}$ のときの距離から減じた。これにより, 圧縮荷重 $5.2 \mathrm{~N}$ のときの形状を基準とした各圧縮荷重時のウレタンフ オーム圧縮量を得た.

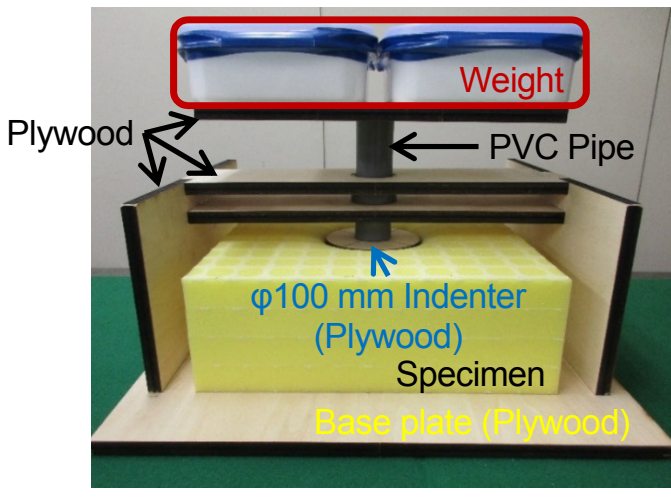

(a) Specimen including contrast media with jig

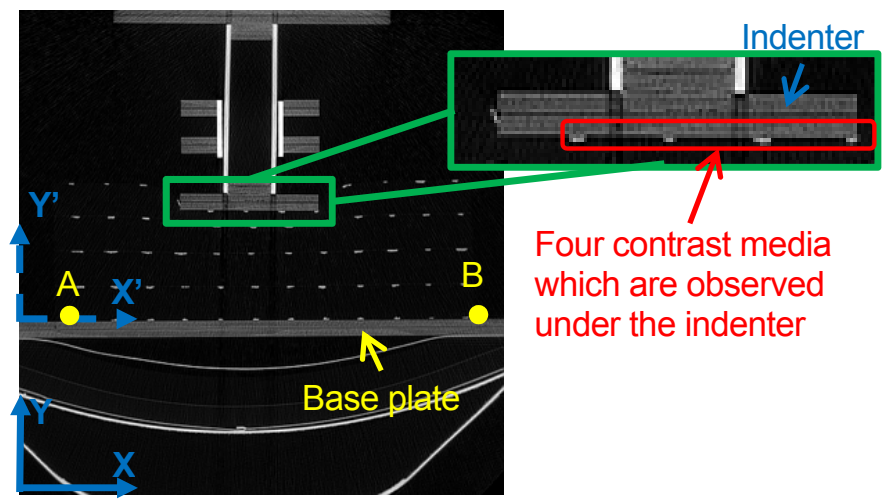

(b) Tomographic image of specimen

Fig. 2 Compression test of the specimen in Fig. 1. (a) Set-up of the specimen in compressive condition. The jig was made of plywood and PVC pipe. Diameter of the indenter was $100 \mathrm{~mm}$, and the weight was $\mathrm{NaCl}$ powder. (b) Tomographic image using $40 \mathrm{~N}$ weight obtained by X-ray CT imaging. We could distinguish the contrast media, the weight, and the indenter. Four points of the contrast media observed just under the indenter were digitized, and the distances to the points from the base plate A-B were measured. 
Funai, Yokota, Hakamata, Fukasaku, Himeno, Suzuki, Maejima and Nakamura,

Transactions of the JSME (in Japanese), Vol.84, No.859 (2018)

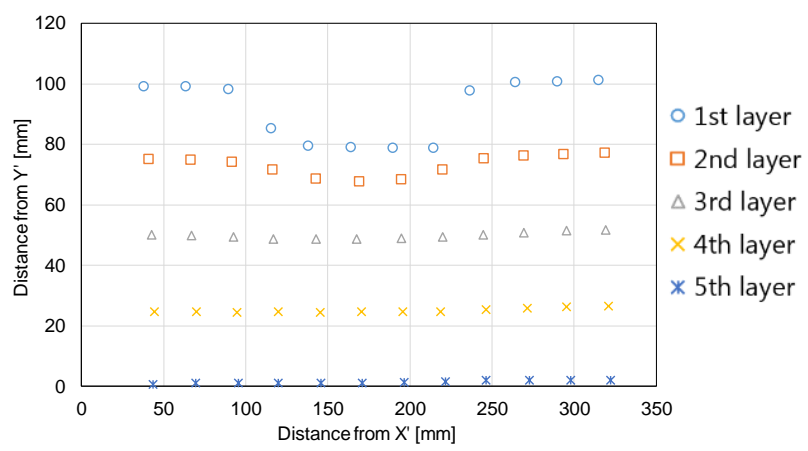

Fig. 3 Result of the compression test using $40 \mathrm{~N}$ weight. This result suggested that the proposed method in this study enabled us to measure not only outside but also inside deformation of the urethane-foam.

\section{$2 \cdot 3$ 提案手法の計測誤差評価}

本研究が提案する変形形状計測手法には， $2 \cdot 2$ 節の画像処理による数值化誤差が計測誤差として見込まれる. この計測誤差を評価するため, $2 \cdot 2$ 節で得た圧縮荷重と変形量の関係を, JIS K6400-2 のウレタンフォームの圧縮 試験方法を参考に実施した万能引張り・圧縮試験機による圧縮試験結果と比較した. 試験は, $2 \cdot 2$ 節と同様に 2 ・ 1 節で作成した造影剤を塗布したウレタンフォームに対して実施することとし， $2 \cdot 2$ 節で使用した治具の圧子と 同じ $\varphi 100 \mathrm{~mm}$ の円板型圧子を，最大測定荷重 $250 \mathrm{~N}$ のロードセルに取り付けた（株）エー・アンド・デイ製テン シロン RTC-2410 で実施した（図 4)。圧縮速度は JIS K6400-2 と同様に $100 \mathrm{~mm} / \mathrm{min}$.とした。 圧縮試験前に, JIS K6400-2 を参考に予備圧縮を行った。 圧縮試験は, サンプリングを約 $0.3 \mathrm{~mm}$ として試験片を約 $70 \mathrm{~mm}$ 圧縮する まで実施した. JIS K6400-2 の圧縮試験は荷重值を $1 \mathrm{~N}$ 単位で読み取ることとしているが，本研究では少なくとも $1 / 10 \mathrm{~N}$ まで読み取った。得られた荷重 - 変位曲線を, 2 ・2 節と同様に, 荷重 $5.2 \mathrm{~N}$ のとの変形量を 0 として図 5 の青の実線で示す.また， 2 ・2 節で計測した結果も同様に荷重 $5.2 \mathrm{~N}$ のときの変形量を 0 として図 5 にプロッ トした．万能引張り・圧縮試験機による圧縮試験結果から, 荷重 5.2，10，20，30，40，50，60 N に最も近い圧縮 荷重のときの試験片変形量を抽出して 2 ・2 節の結果との差を算出した. 図中のデータラベルがその結果である. 両者の差の二乗平均平方根を算出したところ, $0.3 \mathrm{~mm}$ であった.

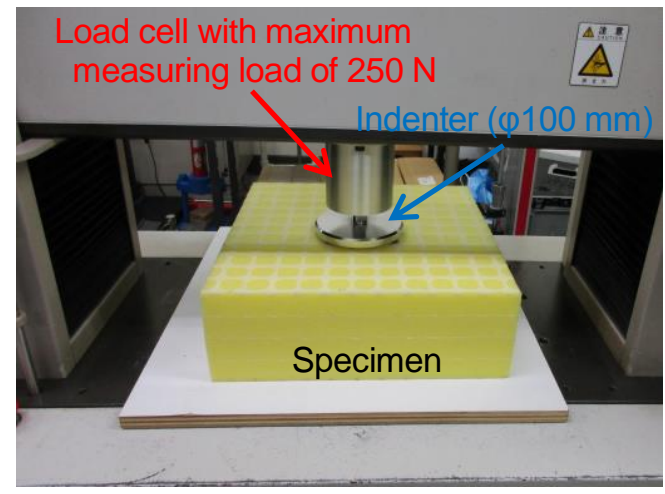

Fig. 4 Compression test based on JIS K6400-2 using a testing machine with $100 \mathrm{~mm}$ diameter indenter and a load cell.

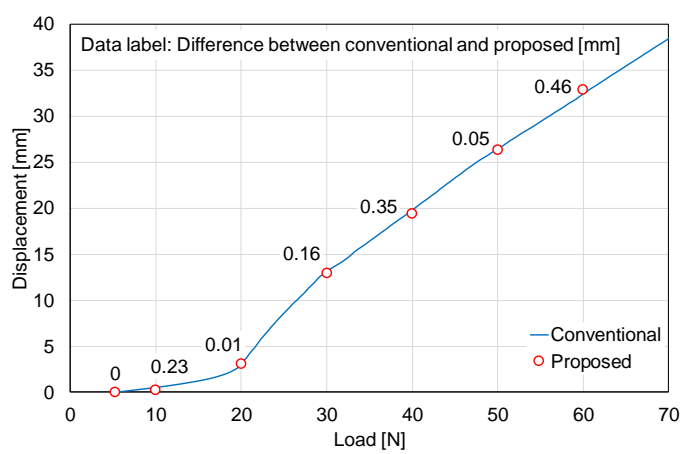

Fig. 5 Comparison of load-displacement behavior between the compression tests in Fig. 2 and Fig. 4. "Proposed" represent the result from the test in Fig. 2, and "Conventional" does one in Fig. 4.

\section{3. マットレスへの応用}

\section{$3 \cdot 1$ 撮影用マットレスの作製}

撮影用マットレスは，被験者が臥床することを想定して $2000 \mathrm{~mm} \times 450 \mathrm{~mm} \times 100 \mathrm{~mm}$ のウレタンフォームで作 製した. マットレスの素材には，2 章と同様に（株）イノアックコーポレーション製のウレタンフォーム ER-1 を 使用した. 図 6 のように, ウレタンフォームを厚さ方向に 4 枚に切断し, 各層の上面および最下層の裏面の合計 
Funai, Yokota, Hakamata, Fukasaku, Himeno, Suzuki, Maejima and Nakamura,

Transactions of the JSME (in Japanese), Vol.84, No.859 (2018)

5 面（図 6(b) 1st〜 5th layer）に，造影剤を $25 \mathrm{~mm} \times 25 \mathrm{~mm}$ の格子状に塗布した．塗布した範囲は，被験者の体幹 部に相当する部位が載る範囲となる身長方向に $850 \mathrm{~mm}$ の範囲とした．造影剤は，2 章と同様に（株）ポリシス製 のゲル PL-00 を使用した．造影剤の塗布および接着も 2 章と同様の手法で実施した.

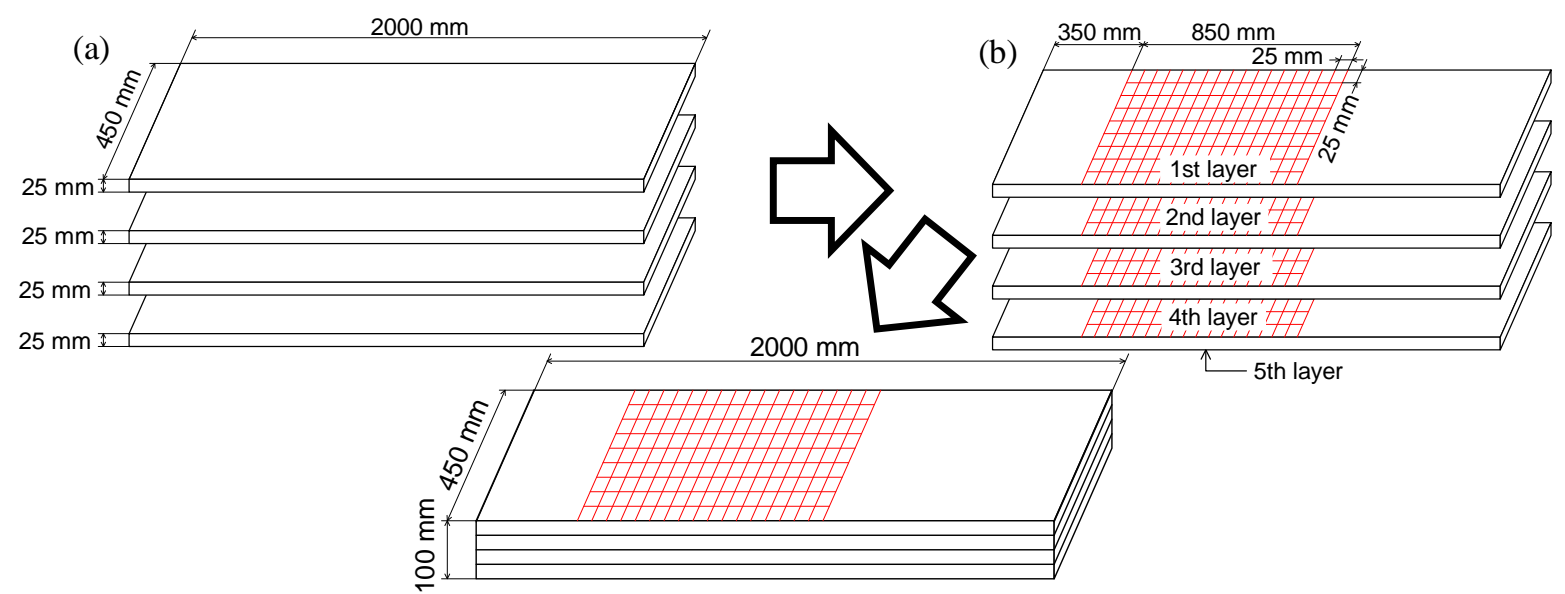

Fig. 6 Preparation of the radiographic mattress submitted to an experiment. (a) Four urethane-foam sheets were used. (b) Lattice-like lines were drawn using contrast medium on top surface of each sheet (1st to 4th layer) and bottom surface of the lowest sheet (5th layer). (c) They were piled up and glued.

\section{$3 \cdot 2$ 人体模型の作製}

X 線 CT 撮影に使用する人体模型は，メタルアーチファクトの発生を回避するため，光造形法を用いて樹脂で 作製した．横田らが構築した人体モデル（横田，姫野,2008）と，同じく横田らが開発したボクセルエディタ（横 田他, 2005）を用いて，図 7(a)に示寸ような全身ポリゴンデータを作成した。続いて，Geomagic Studio 2014 によ り頭部と四肢を除いた形状データを作成し，さらに Coronal 断面で切断することでマットレスと接触する背中側 のみの形状データを作成した（図 7(b)). 人体模型は，下面を人体背中側形状，上面を開口部とした 8 つのパーツ に分割して造形し，樹脂製のボルトおよびナットで締結した（図 8).人体模型には，体幹部の重量を付与するこ ととし，この重量を阿江らの報告に基づいて算出した（阿江他, 1992)。そ結果，体幹部の質量は $33.2 \mathrm{~kg}$ であっ た．本研究では，撮影用マットレスの変形量を大きくするため，同じく阿江らの報告に記載された身体部分慣性 特性の標準偏差 $\sigma$ を活用し，人体模型の重量を「平均 $+3 \sigma 」$ となる $38.1 \mathrm{~kg}$ とした．この重量を分割された 8 パ ーツに均等に負荷するため，約 $4.76 \mathrm{~kg}$ を目標として各パーツに樹脂製ペレット（(株）サンプラテック製硬質塩 化ビニル）を充填した．模型にペレットを充填しても目標の重量に満たなかったため，食塩（NaCl $99 \%)$ を充填 した樹脂製ケースをパーツごとに人体模型上に載せて目標重量を達成した。

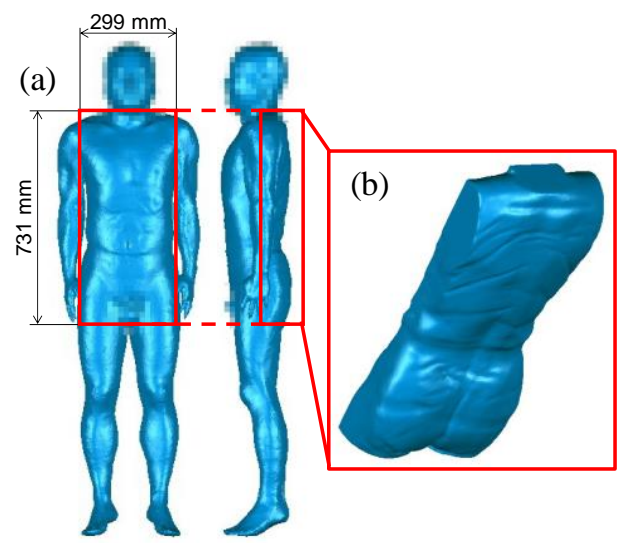

Fig. 7 3D shape data of the manikin. (a) Human body model constructed by Yokota et al. (b) Dorsal aspect of human body model.

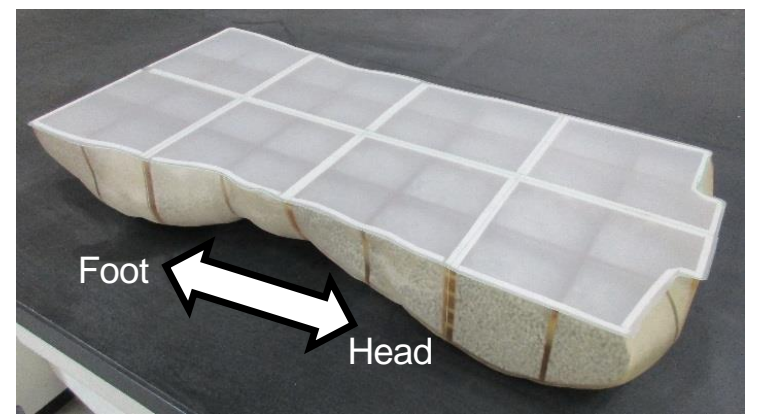

Fig. 8 Manikin in imitation of dorsal shape of human trunk being. In order to replicate the weight of human trunk part, the manikin was filled with resin pellets, and boxes filled with $\mathrm{NaCl}$ powder were further put on it. 
Funai, Yokota, Hakamata, Fukasaku, Himeno, Suzuki, Maejima and Nakamura,

Transactions of the JSME (in Japanese), Vol.84, No.859 (2018)

\section{$3 \cdot 3 \mathrm{X}$ 線 CT 撮影}

マットレスの変形状態を可視化するため，作製した撮影用マットレスの造影剤を塗布した領域に人体模型を載 せて X 線 CT 撮影を行った．撮影用マットレスを $2000 \times 470 \times 20 \mathrm{~mm}$ のアクリル板に載せ，その上にウェイトを 載せた人体模型を配置した．撮影条件は $2 \cdot 2$ 節と同様とした．撮影範囲は，図 9 に示すように人体模型全体を含 むように設定した．撮影後，約 $1 \mathrm{~mm}$ ピッチのボクセルデータとなるように再構成を行った．X 線 CT 撮影から は Axial 断面画像が得られた. 得られた断面画像を ImageJ で切断断面を変更し, Sagittal 断面画像を作成した。 マ ットレスの変形形状を計測するため, 図 9 に示す 9 断面の断層画像を抽出した. 断層画像の代表として, Section 3 およびSection 11 の断層画像を図 10 に示す. 画像に目立ったアーチファクトは確認されなかった. 図 $10 よ り$, 断層画像に人体模型，ウェイト，アクリル板，X 線 CT のベッドが撮影されていることを確認した. また，2・2 節と同様に，マットレスに塗布した造影剤が点となって撮影できていることを確認した（図 10 拡大図）.

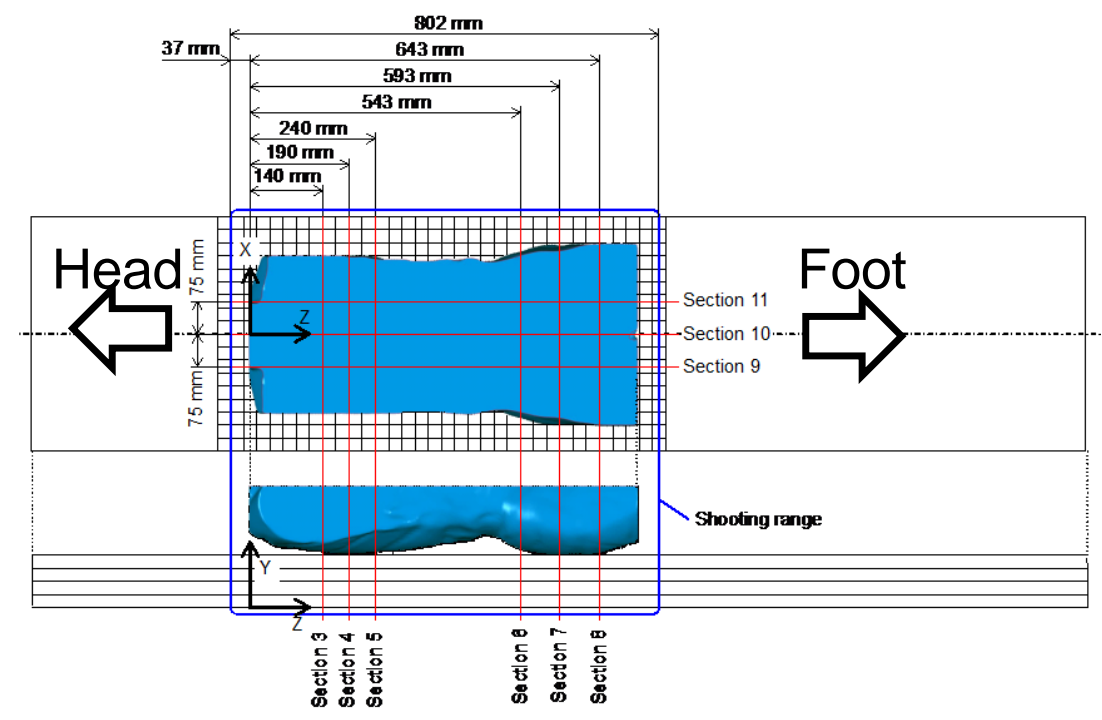

Fig. 9 Axial and sagittal cross-sections used to measure the mattress deformation. All the images obtained from X-ray CT were axial section images. Reconstruction from axial to sagittal images was performed using ImageJ, and the sectional images (Section 3 to 11 in the figure) were extracted.

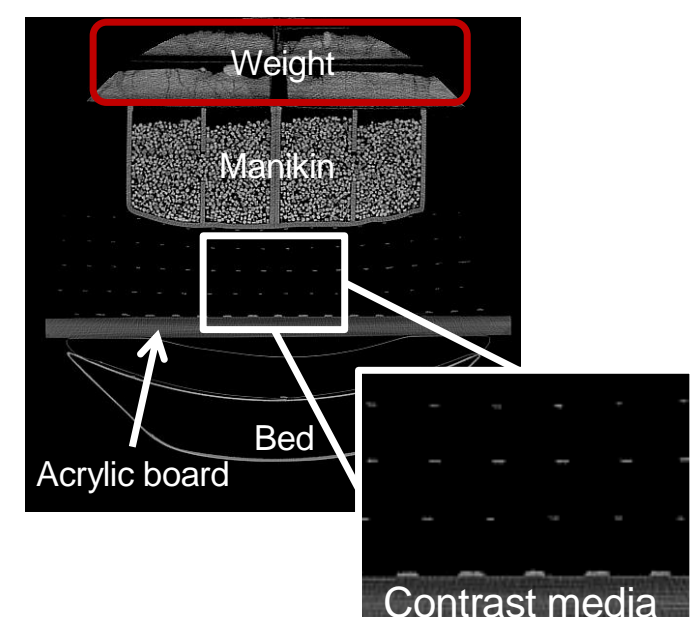

(a) Axial section image

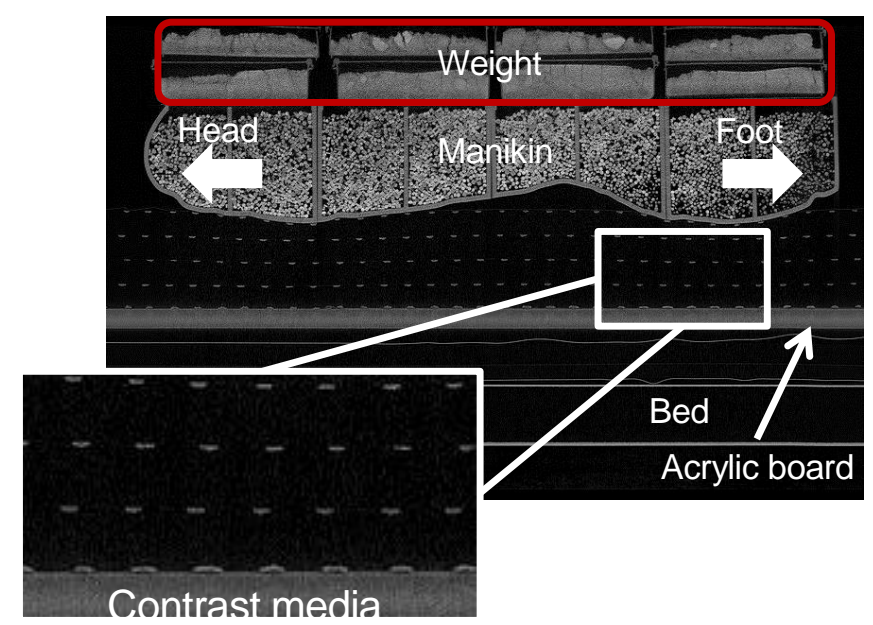

(b) Sagittal section image

Fig. 10 Sectional images of the radiographic mattress with manikin. (a) Axial section. (b) Sagittal section. The phantoms of contrast media could be seen inside the mattress. 
Funai, Yokota, Hakamata, Fukasaku, Himeno, Suzuki, Maejima and Nakamura,

Transactions of the JSME (in Japanese), Vol.84, No.859 (2018)

\section{$3 \cdot 4$ マットレス変形形状の計測}

抽出した 9 断面のマットレス変形状態, 寸なわち造影剂の像の座標值を, ImageJ を用いて計測した. 断層画像 には，造影剤の像の他に人体模型や模型に載せたウェイト，アクリル板，X線 CT のベッドが撮影されている. 造影剂の位置を計測するため, 造影剤とその他で分類する二值化を試みた，二值化作業は, $2 \cdot 2$ 節と同様の手順 で行った．この作業でその他の領域に分類できず，かつ明らかに造影剤の像ではない領域を，手作業でその他の 領域に分類した. 次に, 輝度値による重みづけを行った各像の重心座標を算出した. この作業も $2 \cdot 2$ 節と同様の 手順で行った．作業は，DICOM の Tag 情報に記載された 1 画素当たりの長さを反映した結果が出力されるよう に配慮した. 今回の撮影では, 図 9 に示した座標系の X, Y 方向が, 1 画素当たり $0.975 \mathrm{~mm}, \mathrm{Z}$ 方向が $1 \mathrm{~mm}$ で あった。このような作業を，図９に示した 9 断面の断層画像に対して実施し，空間における造影剤の位置を計測 した. なお計測結果は，図 9 に示寸座標系の值となるように配慮した，具体的には，撮影結果である Sagittal 断面 が図 9 の $\mathrm{YZ}$ 平面と平行となるように設定し, また $\mathrm{Z}=0$ および $\mathrm{X}=0$ は, Axial および Sagittal 断面画像より目視で それぞれ模型左端 (頭部切断面), および図 8 の人体模型を構成する桶の $\mathrm{X}$ 軸方向の境界に相当する断層画像の 位置とした. $\mathrm{Y}=0$ は, Section 3 11 の 5th layer の各造影剤の像の重心座標からその像の $\mathrm{Y}$ 方向長さの二分の一の 長さを減じた值を計算し, その平均值とした. Axial 断面の変形状態を計測した結果の代表として, Section 3 の数 值化結果を図 11 (a)に, Sagittal 断面の代表として, Section 11 の数值化結果を図 11 (b)に示す.

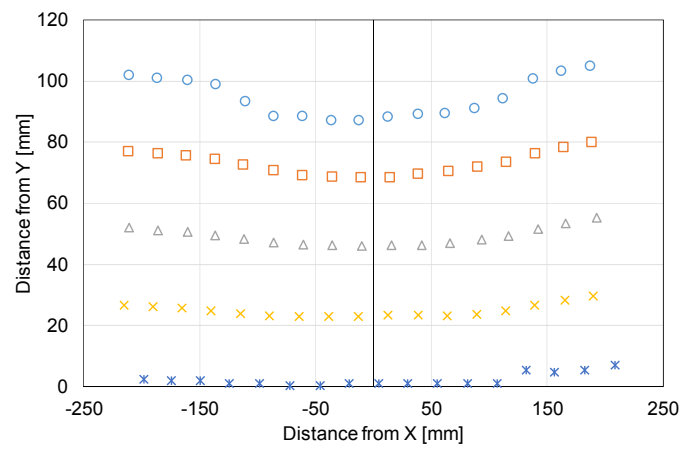

(a) Section 3

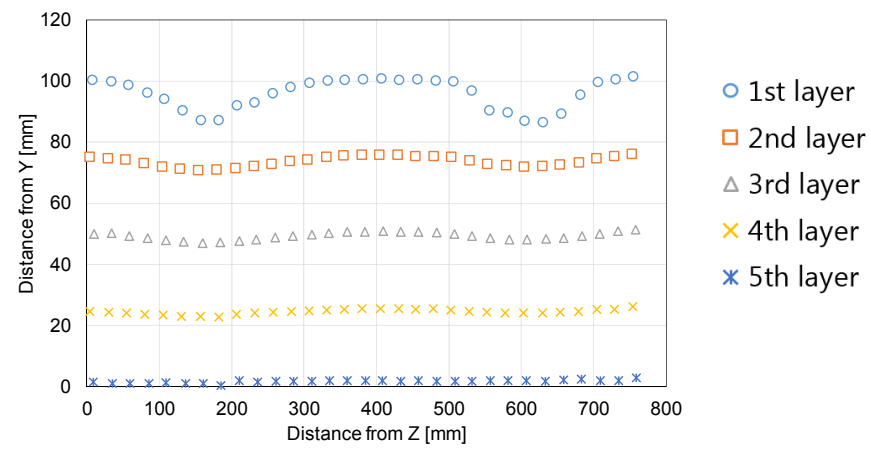

(b) Section 11

Fig. 11 Deformation of radiographic mattress with manikin. (a) Axial section. (b) Sagittal section. Not only outside but also inside deformation of the urethane-foam could be measured.

\section{4. 考 察}

本研究ではウレタンフォームの変形量を計測するために，造影剤を塗布したウレタンフォームの X 線 CT 撮影 を行った．造影剤には（株）ポリシス製のゲル（PL-00）を使用した。このゲルは，X線 CT 用の造影剤として用 意されたものではないが, 図 2 および図 10 の断層画像に明確な像として撮影することができた. 医療用 X 線 CT は，撮影対象の密度の差を画像化し， CT 值は水が 0 , 空気が-1000 となるように調整されている. 本研究に使用 した PL-00 とウレタンフォームの密度はそれぞれ $1.1 \mathrm{~g} / \mathrm{cm}^{3}, 3.5 \times 10^{-2} \mathrm{~g} / \mathrm{cm}^{3}$ である. PL-00 はウレタンフォームの 約 31 倍の密度を有している. この密度差により, 断層画像のウレタンフォームとゲルに明確なコントラストが生 じ, PL-00 が造影剂として機能したと考える. 反面, 人体の密度は約 $1.1 \mathrm{~g} / \mathrm{cm}^{3}$ であることから（蜂須賀他, 1970), ゲルと人体が接した状態では両者の判別が困難になる可能性がある. 人体との区別も明確にしたい場合, $1.1,3.5$ $\times 10^{-2} \mathrm{~g} / \mathrm{cm}^{3}$ いずれとも異なる密度を有する造影剤を選定する必要があると考える．本研究では，X線 CT を用い てウレタンフォームの変形量計測および内部の変形状態観察を行ったが, 使用した造影剤は著者らにより MRI で も可視化できることが確認されている（Funai et al., 2015)．そのため，X線 CT に比べて分解能は下がるが，MRI を用いることでマットレス変形量と, 人体内部組織の詳細な観察が期待できる.

本研究では, 万能引張り・圧縮試験機による圧縮試験結果を基準として提案手法の誤差評価を行った. その結 果計測誤差は両者の二乗平均平方根で $0.3 \mathrm{~mm}$ であった（図 5).この誤差值の妥当性について考える. ウレタン の圧縮特性は，JIS K6400-2 に示される直方体試験片を円板型圧子で圧縮した試験により代表される．金井らは， 
Funai, Yokota, Hakamata, Fukasaku, Himeno, Suzuki, Maejima and Nakamura, Transactions of the JSME (in Japanese), Vol.84, No.859 (2018)

この試験の結果に基づいてウレタンフォームの選定を行い，自動車用シートの座り心地の評価を行った（金井他， 2004）。このことから，人体のような複雑な形状が載った際のクッション特性も，JIS K6400-2 で代表されると考 えられ, 基準とする試験は妥当なものと考える. 次に, 提案手法のサンプリング数について考える. 万能引張り・ 圧縮試験機による試験は圧縮速度 $100 \mathrm{~mm} / \mathrm{min}$.で連続的に実施しているため実線となる（図 5)。この試験結果か ら, ウレタンフォームの圧縮特性は約 $20 \mathrm{~N}$ 圧縮された付近に変曲点を持ち, 無負荷状態から約 $20 \mathrm{~N}$ 圧縮まで, また約 $20 \mathrm{~N}$ から約 $60 \mathrm{~N}$ 圧縮までそれぞれほぼ直線的な荷重 - 変位曲線を描く. 提案手法では約 $10 \mathrm{~N}$ おきにウ レタンフォーム変形量を計測したが，直線的な変形挙動を示寸範囲をそれぞれ 2 点以上計測しているため，ウレ タンフォームの変形挙動を再現するに十分な点数を計測していると判断できる. また，二乗平均平方根は測定点 数により平均化されているため測定点数に大きく依存しない值であり，比較点数を増やしても大きな変化は見込 めない. 以上のことから, 本研究で実施した誤差評価手法は適切なものであり, 約 $60 \mathrm{~N}$ 圧縮するまでの計測誤差 は先に算出した $0.3 \mathrm{~mm}$ と考えることができる. ウレタンフォームの硬さ測定規格である JIS K6400-2 では, 圧縮 時の荷重を $1 \mathrm{~N}$ まで読み取ることとしており，1 N 未満の測定值に丸め誤差が発生する. 本研究で実施した万能 引張り・圧縮試験機による荷重值測定は, 少なくとも $1 / 10 \mathrm{~N}$ まで読み取っているため, 計測誤差 $0.3 \mathrm{~mm}$ はこの 丸め誤差を含まない值である. 図 5 の Conventional のグラフより, 今回対象としたウレタンフォームの圧縮荷重 が $1 \mathrm{~N}$ 変動したときの変位量は, 最大で約 $0.7 \mathrm{~mm}$ 変化する. すなわち $1 \mathrm{~N}$ 未満の測定值を丸めた時の誤差を長 さで表現すると約 $0.7 \mathrm{~mm}$ となる. 図 5 より, 本研究が提案する X 線 CT 撮影の計測誤差は, 二乗平均平方根で $0.3 \mathrm{~mm}$, 最大で $0.46 \mathrm{~mm}$ であるため, 本研究が提案する計測手法の精度は JIS K6400-2 が定める試験方法とほぼ 同程度かわずかに良好といえる。

図 11 は，人体模型を載せた撮影用マットレスを X 線 CT で撮影し，塗布された造影剤の位置を数值化した結 果である. 図 11 (b)に代表される Sagittal 断面の数值化結果が, 寝姿勢計測装置（中嶋, 1998）の結果と同様に, 体 表の $\mathrm{S}$ 字カーブを反映していることを目視で確認した。嶋根ら, 河合ら, 中嶋は寝具表面の変形状態のみを計測 対象としていたが，提案手法はマットレス内部の変形状態も数值として扱えることを示している（嶋根他, 1993, 河合他, 1998, 中嶋, 1998)。また，本研究の X 線 CT 撮影は人体の脊椎を撮影寸る際の条件と同じであるため, 作 製した撮影用マットレスに被験者が臥床した状態を撮影することで佐藤の報告と同様に人体内部の状態観察が期 待できる (佐藤, 1995)。このことから, 本研究で提案する手法で被験者がマットレスに臥床した時のマットレス 表面および内部の変形状態と人体内部状態を同時に可視化できると考える. 著者らは, 身体負荷の少ないマット レスを実現するために，使用者の体の形状や重量配分に合わせてマットレスの硬さを部分的に変更した設計を検 討している，具体的には，図 1 の試験片を構成する 4 層のウレタンフォームのうちの 1 層, あるいは複数の層の 素材を変更して圧縮特性を変え, それを複数並べた構造となる. このような構造のマットレスに使用者が臥床す ると, 柔らかい層が大きく圧縮され，硬い層は小さな変形しか起こさない，すなわち，内部の変形状態が場所ご とに異なることとなる.著者らは, 使用者個々に対しては生体力学シミュレーションによる設計を検討している. この生体力学シミュレーション技術の開発には内部の変形状態が異なるマットレスの変形挙動を生体力学シミュ レーションで再現し, 実験結果と比較する必要がある. 本研究の提案手法により, 生体力学シミュレーションの 精度検証に必要となるマットレス内外部の変形量計測が可能になったと考える.

本研究で提案した計測手法は，マットレスだけでなくウレタンフォーム製品全般に対して適用可能な技術であ ると考える. 寸なわち, 枕や自動車用の座席に適用することで使用時におけるそれらの変形状態を内部まで可視 化が期待でき，これらの製品開発において有用な基礎技術であると考える.

\section{5. 結 言}

本研究では, ウレタンフォームの表面および内部の変形形状を計測する手法として, 格子状の造影剤を有する ウレタンフォームを X 線 CT で撮影する方法を提案した. さらに, 提案手法をマットレスに適用し, 人が臥床し た状態を想定したマットレスの変形形状計測を試みた。得られた結果をまとめると以下のようになる.

(1) 造影剤を格子状に塗布することで, X 線 CT でウレタンフォームの変形状態が撮影でき, 画像処理で造影 阂の座標值計測を行うことで変形形状計測が可能であることを示した. 
Funai, Yokota, Hakamata, Fukasaku, Himeno, Suzuki, Maejima and Nakamura,

Transactions of the JSME (in Japanese), Vol.84, No.859 (2018)

（2）造影剤をウレタンフォーム表面だけでなく内部にも塗布することで，これまで実施できなかったウレタン フォーム内部の変形形状を把握することを可能とした.

（3）造影剤塗布，画像の数值化などによる提案手法の計測誤差を評価した結果， $0.3 \mathrm{~mm}$ 程度であった.

（4）提案手法をマットレスに適用し，体重に相当する荷重を有した人体模型を配置した状態を X 線 CT で撮影 することで，人が臥床した状態を模したマットレスの変形形状計測が可能であることを示した．また前述 のウレタンフォームと同様に，マットレス内部の変形形状を把握する事を可能とした.

以上のことから，本研究で提案するウレタンフォーム変形形状計測手法により，マットレスの表面および内部 の変形形状を計測することができた。また，これまでの寝具の変形量計測および寝姿勢計測で検証されていない 測定結果の計測誤差についても, 一定の数值として示すことができた.

\section{文献}

Abràmoff, M. D., Magalhães, P. J. and Ram, S. J. , Image processing with ImageJ, Biophotonics International, Vol. 11, No. 7, (2004), pp. 36-42.

阿江通良, 湯 海鵬，横井孝志，日本人アスリートの身体部分慣性特性の推定，バイオメカニズム, Vol. 11 (1992), pp. 23-33.

Arganda-Carreras, I., Cardona, A., Kaynig, V. and Schindelin, J., Trainable Weka segmentation, available from <http://imagej.net/Trainable_Weka_Segmentation>, (参照日 2017 年 4 月 25 日).

船井 孝, 長津義之, 山口進吾, 鈴木敬明, 加藤俊文, 片岡弘之, 横田秀夫, 姫野龍太郎, 超弹性を考慮した生体組 織の物性值データベース構築, 第 20 回バイオエンジニアリング講演会講演論文集, (2008), pp. 231-232.

Funai, T., Suzuki, T., Nakamura, S., Yokota, H., Hakamata, Y. and Maejima, F., Estimating mattress deformation with a person in the supine position using biomechanical simulation, The Proceedings of the 8th Asian-Pacific Conference on Biomechanics (2015), p. 264.

蜂須賀弘久, 水野 勇, 山岡誠一, 吉村寿人, 人体密度ならびに体脂肪量の年齢別推移について, 栄養と食糧, Vol. 23, No. 1 (1970), pp. 46-50.

Ijiri, T. and Yokota, H., Contour-based interface for refining volume segmentation, Computer Graphics Forum, The International Journal of Eurographics Association (Proc. of Pacific Graphics), Vol. 29, No. 7 (2010), pp. 2153-2160.

日本規格協会, 軟質発泡材料一物理特性一第 2 部 : 硬さ及び圧縮応力一ひずみ特性の求め方, JIS K 6400-2:2012 (2012).

金井博幸, 中野佑治, 辻 創, 石澤広明, 鳥羽栄治, 西松豊典, 座部パッドの反発弹性率が自動車シートの座り心地 に及ぼす影響, 感性工学研究論文集, Vol. 5, No. 1 (2004-2005), pp. 7-12.

河合貴美子, 辻井彰司, 西中久雄, 原田隆司, 寝姿勢の測定方法, 繊維製品消費科学, Vol. 39, No. 5 (1998), pp. 54-56. 小暮貴政, 西村泰昭, 西村 章, 白川修一郎, 入眠姿勢での寝心地が睡眠に及ぼす影響, 日本生理人類学会誌, Vol. 12, No. 4 (2007), pp. 171-176.

前橋基樹, 森田康之, 山田 宏, 円筒面により圧縮されたウレタンフォームの X 線 CT 撮像と変形解析, 日本機械 学会 九州支部 第 70 期総会・講演会, (2017), pp. 241-242.

長岡智明, 櫻井清子, 国枝悦夫, 渡辺聡一, 本間寛之, 鈴木 保, 河合光正, 酒本勝之, 小川幸次, 此川公紀, 久保田 勝巳, 金 鳳沫, 多氣昌生, 山中幸雄, 渡辺 敏, 日本人成人男女の平均体型を有する全身数值モデルの開発, 生体医工学 : 日本エム・イー学会誌, Vol.40, No.4 (2002), pp. 45-52.

中嶋敦史, 寝姿勢計測装置の開発, 豊田中央研究所 R\&D レビュー, Vol. 33, No. 3 (1998), p. 115.

Rasband, W. S., ImageJ, U. S. National Institutes of Health, Bethesda, Maryland, USA, (1997-2016), $<$ https://imagej.nih.gov/ij/>, (参照日 2017 年 4 月 25 日).

佐藤公治, ジェリーマット上における腰椎 alignment の MRI による解析, 日本腰痛学会誌, Vol. 1, No. 1 (1995), pp. 27-31.

Schneider, C. A., Rasband, W. S. and Eliceiri, K. W., NIH image to ImageJ: 25 years of image analysis, Nature Methods, Vol. 9, No. 7 (2012), pp. 671-675.

嶋根歌子, 田村照子, 敷布団の圧縮特性と寝姿勢からの体圧分布予測, 睡眠と環境, Vol. 1, No. 1 (1993), pp. 36-43.

田村照子, 嶋根歌子, 洪 淳淑, 吉田 誠, 機構的観点から見た敷布団の快適性と健康性, 日本家政学会誌, Vol. 40, No. 8 (1989), pp. 705-711.

山田 宏, 宮本俊輝, 森田康之, 前橋基樹, 円筒状突起に対する二層式マットレスの変形測定とウレタンフォーム 
Funai, Yokota, Hakamata, Fukasaku, Himeno, Suzuki, Maejima and Nakamura, Transactions of the JSME (in Japanese), Vol.84, No.859 (2018)

の圧縮特性に基づく圧力分布の予測, M \& M 2016 材料力学カンファレンス講演論文集, (2016), pp. 386-387. 山崎信寿, 佐藤真一, 立川律哉, 寝具クッションの生体力学的快適化, バイオメカニズム, Vol. 12 (1994), pp. 61-71. 横田秀夫, 姫野龍太郎, 生体力学シミュレーションのための人体モデル構築, 日本ロボット学会誌, Vol. 26, No. 3 (2008), pp. 218-221.

横田秀夫，西村将臣，中村佐紀子，深作智明，牧野内昭武，姫野龍太郎，VCAT による固体別モデリング，日本機械 学会 2005 年度年次大会講演論文集, 2005.5 (2005), pp. 145-146.

Yonezu, A., Hirayama, K., Kishida, H. and Chen, X., Characterization of the compressive deformation behavior with strain rate effect of low-density polymeric foams, Polymer Testing, No. 50 (2016), pp. 1-8.

\section{References}

Abràmoff, M. D., Magalhães, P. J. and Ram, S. J. , Image processing with ImageJ, Biophotonics International, Vol. 11, No. 7, (2004), pp. 36-42.

Ae, M., Tang, H. and Yokoi, T., Estimation of inertia properties of the body segments in Japanese athletes, Journal of the Society of Biomechanisms Japan, Vol. 11 (1992), pp. 23-33 (in Japanese).

Arganda-Carreras, I., Cardona, A., Kaynig, V. and Schindelin, J., Trainable Weka segmentation, available from <http://imagej.net/Trainable_Weka_Segmentation>, (accessed on 25 April, 2017).

Funai, T., Nagatsu, Y., Yamaguchi, S., Suzuki, T., Kato, T., Kataoka, H., Yokota, H. and Himeno, R., A database of superelastic property functions of organs for biomechanics simulation, Proceedings of the 20th Bioengineering Conference (2008), pp. 231-232 (in Japanese).

Funai, T., Suzuki, T., Nakamura, S., Yokota, H., Hakamata, Y. and Maejima, F., Estimating mattress deformation with a person in the supine position using biomechanical simulation, The Proceedings of the 8th Asian-Pacific Conference on Biomechanics (2015), p. 264.

Hachisuka, H., Mizuno, I., Yamaoka, S. and Yoshimura, H., Change in density of human body and its fat content with special references to age, Eiyo to Shokuryo, Vol. 23, No. 1 (1970), pp. 46-50 (in Japanese).

Ijiri, T. and Yokota, H., Contour-based interface for refining volume segmentation, Computer Graphics Forum, The International Journal of Eurographics Association (Proc. of Pacific Graphics), Vol. 29, No. 7 (2010), pp. 2153-2160.

JAPANESE STANDARDS ASSOCIATION, Flexible cellular polymeric materials -- Physical properties -- Part 2: Determination of hardness (indentation technique) and stress-strain characteristics in compression, JIS K 6400-2:2012 (2012) (in Japanese).

Kanai, H., Nakano, Y., Tsuji, H., Ishikawa, H., Toba, E. and Nishimatsu, T., Influence of impact resilience on sitting of automotive seat, Journal of Japan Society of Kansei Engineering, Vol. 5, No. 1 (2004-2005), pp. 7-12 (in Japanese).

Kawai, K., Tsujii, S., Nishinaka, H. and Harada, T., Journal of the Japan Research Association for textile end-uses, Vol. 39, No. 5 (1998), pp. 54-56 (in Japanese).

Kogure, T., Nishimura, Y., Nishimura, A. and Shirakawa, S., The relationship between the comfort in a hypnagogic posture and sleep, Japanese Journal of Physiological Anthropology, Vol. 12, No. 4 (2007), pp. 171-176 (in Japanese).

Maebashi, M, Morita, Y. and Yamada, H., X-ray CT imaging and deformation analysis on a low resilience polyurethane foam under compression by a cylindrical surface, The Proceedings of Conference of Kyushu Branch (2017), pp. 241-242.

Nagaoka, T., Sakurai, K., Kunieda, E., Watanebe, S., Honma, H., Suzuki, T., Kawai, M., Sakamoto, K., Ogawa, K., Konokawa, K., Kubota, K., Kim, B., Taki, M., Yamanaka, Y. and Watanabe, S., The development of whole-body high-resolution voxel models of the average Japanese adult male and female, Transactions of the Japanese Society for Medical and Biological Engineering, Vol.40, No.4 (2002), pp. $45-52$ (in Japanese).

Nakajima, A., Measuring apparatus for sleeping posture of human bodies, R\&D Review of Toyota CRDL, Vol. 33, No. 3 (1998), p. 115 (in Japanese).

Rasband, W. S., ImageJ, U. S. National Institutes of Health, Bethesda, Maryland, USA, (1997-2016), available from $<$ https://imagej.nih.gov/ij/>, (accessed on 25 April, 2017).

Sato, K., MRI analysis of lumber spine alignment on jelly mat, The journal of Japanese Society of Lumber Spine Disorders, Vol. 1, No. 1 (1995), pp. 27-31 (in Japanese).

Schneider, C. A., Rasband, W. S. and Eliceiri, K. W., NIH image to ImageJ: 25 years of image analysis, Nature Methods, Vol. 9, No. 7 (2012), pp. 671-675.

Shimane, U. and Tamura, T., Evaluation of pressure distribution in supine position by compressive stress-strain mattress 
relationship, J. Sleep and Environments, Vol. 1, No. 1 (1993), pp. 36-43 (in Japanese).

Tamura, T., Shimane, U., Hou, S. and Yoshida, M., Evaluation of comfort and health of mattress from mechanical standpoint, Journal of Home Economics of Japan, Vol. 40, No. 8 (1989), pp. 705-711 (in Japanese).

Yamada, H., Miyamoto, T., Morita, Y. and Maebashi, M., Deformation measurement of double layer mattress for cylindrical protrusion and theoretical prediction of pressure distribution based on compressive characteristics of polyurethane foams, The Proceedings of the Materials and Mechanics Conference (2016), pp. 386-387 (in Japanese).

Yamazaki, N., Satoh, S. and Tachikawa, R., Biomechanical fitting of bed mattresses, Biomechanisms, Vol. 12 (1994), pp. 6171 (in Japanese).

Yokota, H. and Himeno, R., Development of human model for biomechanical simulation, Journal of Robotics Society of Japan, Vol. 26, No. 3 (2008), pp. 218-221 (in Japanese).

Yokota, H., Nishimura, M., Nakamura, S., Fukasaku, K., Makinouchi, A. and Himeno, R., Individual modeling using a VCAT system, The proceedings of the JSME annual meeting, 2005.5 (2005), pp. 145-146 (in Japanese).

Yonezu, A., Hirayama, K., Kishida, H. and Chen, X., Characterization of the compressive deformation behavior with strain rate effect of low-density polymeric foams, Polymer Testing, No. 50 (2016), pp. 1-8. 